\title{
Pengupahan Perspektif Ekonomi Islam Pada Perusahaan Outsourcing
}

\author{
Oleh: \\ Hendy Herijanto \\ Muhammad Nurul Hafiz
}

Sekolah Tinggi Ekonomi Syariah (STES) Islamic Village Tangerang Jl. Islamic Raya Kelapa Dua Tangerang-Banten

Abstrak: Penelitian ini bertujuan untuk mengetahui dan menjelaskan pandangan Ekonomi Islam terhadap sistem pengupahan pada PT. Samuderanayaka Grahaunggul. Menggunakan metodologi penelitian kualitatif dalam penelitian yang bersifat lapangan (field research) ini. Sumber data diperoleh langsung dari lokasi penelitian yang bertempat di kantor pusat PT. Samuderanayaka Grahaunggul melalui dokumen yang berkaitan dengan permasalahan yang diteliti. Selain itu, data juga didapat melalui wawancara dengan General Manager perusahaan tersebutdan Manager Accounting Finance Officer. Setelah terkumpul dengan lengkap kemudian dianalisis secara deskriftif dimana data- data umum yang telah dikumpulkan ditarik kesimpulan secara khusus. Hasil penelitian ini menunjukkan bahwa Secara umum ketentuan pengupahan perusahaan outsourcing yang diberlakukan PT. Sangu terhadap tenaga kerja outsourcing nya telah memenuhi aspek-aspek Syariah Islam, antara lain di tinjau dari perjanjian kerjanya. Karena masalah upah diputuskan oleh mereka yang mengadakan perjanjian kerja. Dalam melaksanakan perjanjian kerja, PT.Sangu memberikan kejelasan kepada tenaga kerja outsourcing baik dari aspek bentuk dan jenis kerjanya, masa kerjanya, maupun upah yang diberikan. Sebagaimana Islam sangat menekankan dalam hal pengupahan harus dengan rasa keadilan dan tidak ada unsur kedzaliman.

Kata Kunci: Aplikasi, Pengupahan, Ekonomi Islam,

\section{Latar Belakang Masalah}

Kedudukan tenaga kerja dewasa ini sangat penting artinya bagi pembangunan bangsa Indonesia. Dasarnya sudah diberikan oleh pendiri bangsa Indonesia, sebagaimana yang tertuang dalam Undang-Undang Dasar Republik Indonesia 1945 (UUD 1945) Pasal 27 Ayat (2) 
menyatakan bahwa, setiap warga Negara Indonesia berhak atas pekerjaan dan kehidupan yang layak bagi kemanusiaan.

Perkembangan ekonomi global dan kemajuan teknologi yang begitu cepat telah membawa banyak perubahan di berbagai sektor, sehingga menimbulkan persaingan usaha yang begitu ketat di semua sektor usaha. Kondisi yang sangat kompetitif ini menuntut dunia usaha untuk menyesuaikan diri dengan tuntutan pasar yang memerlukan respon yang cepat dan fleksibel dalam meningkatkan pelayanan terhadap pelanggan. Untuk memenuhi kebutuhan Sumber Daya Manusia, maka perusahaan yang membutuhkan tenaga kerja memanfaatkan lembaga outsourcing unuk merekrut para tanaga kerja outsourcing.

Hak yang diterima para pekerja outsourcing di perusahaan tempat mereka bekerja tidak setara seperti yang diterima para pekerja tetap diperusahaan tersebut. Padahal dalam bekerja mereka dituntut untuk melakukan hal yang sama seperti halnya pekerja tetap. Para pekerja outsourcing selalu kalah ketika menghadapi perselisihan dengan perusahaan pengguna jasa. Kebijakan dalam memahami hak pekerja outsourcing tampaknya belum terpenuhi. Kondisi ini diperparah oleh kapitalis global dengan jargon-jargon produktivitas, efisiensi dan kompetisinya. Para tenaga kerja tidak mendapat perlakuan dan porsi yang layak sebagai manusia yang bermartabat dalam proses produksi dan dinamika perekonomian. Mereka hanya dipandang sebagai alat produksi yang hampir-hampir tak jauh berbeda dengan mesin produksi lainnya. Ketika para buruh hanya memiliki sumber pendapatan berupa gaji, maka pencapaian kesejahteraan bergantung pada kemampuan gaji dalam memenuhi berbagai kebutuhan hidupnya. Dalam kenyataanya, jumlah gaji relatif tetap, sementara itu kebutuhan hidup selalu bertambah (adanya bencana, sakit, sekolah, tambah anak, harga barang naik, listrik, telepon, biaya transportasi, dan lain- lain). Hal ini menyebabkan kualitas kesejahteraan rakyat (termasuk buruh) semakin rendah. Ironis memang, di satu sisi perusahaan butuh SDM yang berkualitas dan yang mempunyai etos kerja tinggi, namun di sisi lain mereka tidak menghargai para pekerja.

Masalah tenaga kerja memang suatu masalah yang sangat kompleks dan sangat urgen yang seyogyanya mendapat perhatian khusus, maju mundurnya bisnis perusahaan pada khususnya dan perekonomian pada umumnya, tidak lepas dari peran para tenaga kerja atau sumber daya manusia. Oleh karenanya penelitian ini laik untuk diangkat.

\section{Upah}

Upah dalam bahasa Arab sering disebut dengan ajrun atau ajran yang berarti memberi hadiah. Kata ajran mengandung dua arti, yaitu 
balasan atas pekerjaan dan pahala. Upah menurut istilah adalah uang dan sebagainya yang dibayarkan sebagai balas jasa atau bayaran atas tenaga yang telah dicurahkan untuk mengerjakan sesuatu. Upah diberikan sebagai balas jasa atau penggantian kerugian yang diterima oleh pihak buruh karena atas pencurahan tenaga kerjanya kepada orang lain yang berstatus sebagai majikan.

Menurut Afzalurrahman (2005:361), upah merupakan sebagian harga dari tenaga yang dibayarkan atyas jasanya dalam produksi. Menurut Pasal (1) Undang-Undang Nomor 13 Tahun 2003 Ketenagakerjaan, yang dimaksud dengan upah adalah

"hak pekerja yang diterima dan dinyatakan dalam bentuk uang sebagai imbalan dari pengusaha atau pemberi kerja kepada buruh yang ditetapkan dan dibayarkan menurut suatu perjanjian kerja, atau peraturan perundang-undangan, termasuk tunjangan bagi pekerja atau buruh dan keluarganya atas suatu pekerjaan dan atau jasa yang telah atau akan dilakukannya".

Konsep upah menurut Ekonomi Islam, yang pertama adalah prinsip keadilan dan kedua prinsip kelayakan. Mari kita lihat kedua prinsip ini menurut kaca mata Ekonomi Islam.

a. $\quad$ Prinsip Adil. Al Qur'an menegaskan “Berbuat adillah, karena adil itu lebih dekatr kepada taqwa”. (QS. Al-Maidah: 8). Hadis Nabi saw. "Berikanlah upah kepada pekerja sebelum keringatnya kering, dan beritahukan ketentuan upahnya terhadap apa yang dikerjakan". (HR. Baihaqi). Ayat Al Qur'an dan Hadist riwayat Baihaqi di atas, dapat diketahui bahwa prinsip utama keadilan terletak pada kejelasan aqad (transaksi) dan komitmen atas dasar kerelaan melakukannya. Akad dalam perburuhan adalah akad yang terjadi antara pekerja dengan pengusaha. Artinya, sebelum pekerja dipekerjakan, harus jelas dahulu bagaimana upah yang akan diterima oleh pekerja. Upah tersebut meliputi besarnya upah dan tata cara pembayaran upah.

Khusus untuk cara pembayaran upah, Rasulullah Saw bersabda: "Dari Abdillah bin Umar, Rasulullah saw. bersabda: "Berikanlah upah orang sebelum kering keringatnya". (HR. Ibnu Majah dan Imam Thabrani). Dalam menjelaskan hadist ini, Syeikh Yusuf Qardhawi dalam kitabnya Pesan nilai dan Moral dalam Perekonomian Islam, menjelaskan sebagai berikut: Sesungguhnya seorang pekerja hanya berhak atas upahnya jika ia telah menunaikan pekerjaannya dengan semestinya dan sesuai dengan kesepakatannnya, karena umat Islam terikat dengan syarat-syarat antar mereka kecuali syarat yang mengharamkan yang halal atau menghalalkan yang haram. Namun, 
jika ia membolos bekerja tanpa alasan yang benar atau sengaja menunaikannya dengan tidak semestinya, maka sepatutnya hal itu diperhitungkan atasnya (dipotong upahnya) karena setiap hak disamakan dengan kewajiban. Selama ia mendapatkan upah secara penuh, maka kewajiban juga harus dipenuhi. Sepatutnya hal ini dijelaskan secara detail dalam peraturan kerja yang menjelaskan masing-masing hak dan kewajiban kedua belah pihak. Bahkan Syeikh Qardhawi mengatakan bahwa bekerja yang baik merupakan kewajiban karyawan atas hak upah yang diperolehnya, demikian juga memberi upah merupakan kewajiban perusahaan atas hak hasil kerja karyawan yang diperolehnya. Dalam keadaan masa kini, maka aturan-aturan bekerja yang baik itu, biasanya dituangkan dalam buku Pedoman Kepegawaian yang ada di masing-masing perusahaan.

b. Kelayakan (Kecukupan). Jika adil berbicara tentang kejelasan, transparansi serta proporsionalitas ditinjau dari berat pekerjaaanya, maka layak berhubungan dengan besaran yang diterima layak disini bermakna cukup dari segi pangan, sandang dan papan. Dari hadist yang diriwayatkan oleh Abu Dzar bahwa Rasulullah Saw bersabda: "Mereka (para budak) adalah saudaramu, Allah menempatkan mereka di bawah asuhanmua. Sehingga barang siapa mempunyai saudara di bawah asuhannya maka harus diberinya makan seperti apa yang dimakannya sendiri dan memberi pakaian seperti apa yang dipakainya sendiri dan tidak membebankan pada mereka dengan tugas yang sangant berat, dan jika kamu membebankannya dengan tugas seperti itu, maka hendaklah membantu mereka mengerjakannya."(HR. Muslim) Dapat dijabarkan bahwa hubungan antara majikan dengan pekerja bukan hanya sebatas hubungan pekerjaan formal, tetapi karyawan sudah dianggap merupakan keluarga majikan. Konsep menganggap karyawan sebagai keluarga majikan merupakan konsep Islam yang lebih dari 14 abad yang lalu telah disabdakan Rasulullah Saw. Konsep ini dipakai oleh pengusaha-pengusaha arab pada masa lalu, dimana mereka seringkali memperhatikan kehidupan karyawannya diluar lingkungan kerjanya.hal inilah sangat jarang dilakukan saat ini. Upah menurut Islam sangat besar kaitannya dengan konsep moral, upah dalam Islam tidak hanya sebatas materi (kebendaan atau keduniaan) tetapi menembus batas kehidupan, yakni berdimensi akhirat. 


\section{Dasar Hukum Upah Dalam Perpektif Ekonomi Islam}

Sumber hukum Islam yang dipakai dalam menyelesaikan berbagai permasalahan yang terjadi adalah dengan menggunakan al-Qur'an dan Sunnah Nabi, di samping masih banyak lagi sumber hukum yang dapat digunakan. Al-Qur'an sebagai sumber hukum dasar yang menjadi pijakannya.

Allah SWT menegaskan tentang imbalan ini dalam Qur'an Surat At Taubah: 105 yang artinya: "Dan katakanlah: "Bekerjalah kamu,maka Allah dan Rosul-Nya serta orang-orang mukmin akan melihat pekerjaanmu itu, dan kamu akan dikembalikan kepada Allah Yang Maha mengetahui akan ghaib dan yang nyata, lalu diberikan-Nya kepada kamu apa yang kamu kerjakan."(At Taubah: 105)

Dalam Surat At-Taubah ayat 105 menjelaskan bahwa Allah SWT memerintahkan kita untuk bekerja, dan Allah pasti membalas semua apa yang telah kita kerjakan. Pada Ayat ini yang terpenting ialah penegasan Allah bahwasanya motivasi atau niat bekerja itu haruslah benar dan apabila motivasi bekerja tidak benar, maka Allah akan membalas dengan cara memberi azab. Sebaliknya, kalau motivasi itu benar, maka Allah akan membalas pekerjaan itu dengan balasan yang lebih baik dari apa yang kita kerjakan.

Hadits Riwayat Ibnu Majah, artinya: "Berikan kepada seorang pekerja upahnya sebelum keringatnya kering."(HR. Ibnu Majah)

Maksud dari ayat dan hadits tersebut adalah bersegeralah menunaikan hak pekerja setelah selesainya pekerjaan, begitu juga bisa dimaksud jika telah ada kesepakatan pemberian gaji setiap bulan. Al Munawi berkata,

"Diharamkan menunda pemberian gaji padahal mampu menunaikannya tepat waktu". Yang dimaksud memberikan gaji sebelum keringat si pekerja kering adalah ungkapan untuk menunjukan diperintahkannya memberikan gaji segera setelah pekerjaan itu selesai, ketika si pekerja meminta walau keringatnya tidak kering atau keringatnya telah kering."(Faidhul Qodir, 2001:718)

Dasar hukum ujrah dalam ijma, para sahabat dan tabi"in, mereka semua telah membolehkan ujrah. Selain itu pula, ada yang mengatakan bahwa ijma" ulama perkara ujrah kembali kepada nash Al-Quran dan Sunnah Nabi yang suci. Semua ulama bersepakat tidak seorang ulama pun yang membantah kesepakatan ijma"ini.(Kifayatul Akhyar 1994:694)

\section{Rukun dan Syarat Upah (Ujrah)}

Menurut ulama Hanafiyah, rukun ujrah itu hanya satu, yaitu ijab (ungkapan menyewakan) dan qabul (persetujuan terhadap sewa 
menyewa). Akan tetapi, jumhur ulama mengatakan bahwa rukun ujrah itu ada empat, yaitu: a. Orang yang berakad b. Sewa atau imbalan c. Manfaat d. Shighat (ijab-qabul).(A.H Azharudin Latif, 2005:122)

Adapun syarat-syarat akad ijarah adalah sebagai berikut:

a. Untuk orang yang berakad menurut ulama Syafi'iyah dan Hambali, disayaratkan telah baligh dan berakal. Oleh sebab itu, apabila orang yang belum atau tidak berakal seperti anak kecil dan orang gila, menyewakan harta mereka dan diri mereka sebagai buruh menurut mereka ujrahnya tidak sah. Akan tetapi ulama Hanafiyah dan Malikiyah berpendapat bahwa kedua orang yang berakad itu tidak harus mencapai usia baligh.

b. Kedua belah pihak yang berakad menyatakan kerelaannya untuk melakukan akad ijarah. Apabila salah seorang diantaranya terpaksa melakukan akad itu, maka akad ijarahnya tidak sah.

c. Manfaat yang menjadi objek ijarah harus diketahui secara sempurna, sehingga tidak muncul perselisihan di kemudian hari. Apabila manfaat yang akan menjadi objek ijarah itu tidak jelas, maka akadnya tidak sah. Kejelasan manfaat itu dapat dilakukan dengan menjelaskan manfaatnya, dan penjelasan berapa lama manfaat itu ditangan penyewa.

d. Upah atau sewa dalam akad harus jelas

e. Objek ijarah adalah sesuatu yang dihalalkan oleh syara".

\section{Sistem Pembayaran Upah}

Menurut Suparno Eko (2005:158), system pembayaran upah yang umum diterapkan diantaranya:

a. Sistem waktu

Dalam sistem waktu, upah dapat di tentukan dalam bentuk upah per jam, upah per hari, upah per minggu atau upah per bulan. Sistem waktu ini di terapkan jika prestasi kerja sulit di ukur per unitnya. Kebaikam sistem waktu yaitu administrasi pengupahan mudah dan besarnya upah yang dibayarkan tetap.

b. Sistem hasil (output)

Besarnya upah ditetapkan atas satuan unit yang dihasilkan pekerja, seperti per potong, meter, liter dan kilogram. Dalam system hasil, besarnya upah yang dibayar selalu didasarkan kepada banyaknya hasil yang dikerjakan bukan kepada lamanya waktu mengerjakan.

c. Sistem Borongan

Suatu cara pengupahan yang penetapan besarnya jasa didasarkan atau volume pekerjaan dan lama mengerjakannya. Dalam sistem borongan ini pekerja biasa mendapat balas jasa besar atau kecil tergantung atas kecermatan kalkulasi mereka. (Adrian Sutedi, 2011:153) 


\section{Dasar Hukum Upah di Indonesia}

Dalam hukum positif juga diatur tentang pengupahan diantaranya, dalam Undang-Undang Dasar 1945 pasal 27 ayat (2) yang berbunyi “Tiaptiap warga Negara berhak atas pekerjaan dan penghidupan yang layak bagi kemanusiaan".

Dengan upah yang akan diterima oleh buruh atau pekerja yang diberikan haruslah upah yang wajar. (Abner Hutabarat, 1984:13) Disamping itu dalam ketetapan MPR. No IV/MPR/1978 disebutkan kebijaksanaan dibidang perlindungan tenaga kerja ditunjukan kepada perbaikan upah, syarat-syarat kerja, keselamatan kerja, jaminan sosial dalam rangka perbaikan kesejahteraan tenaga kerja secara menyeluruh.

\section{Perbedaan Tingkat Upah}

Dalam beberapa hal, hukum Islam mengakui adanya perbedaan upah di antara tingkat pekerja, karena adanya perbedaan kemampuan serta bakat yang mengakibatkan perbedaan penghasilan dan hasil material. Hal ini sejalan dengan firman Allah SWT dalam Al-Quran An-Nisa ayat 32. Berdasarkan ayat tersebut, penentuan upah pekerja didasarkan atas kemampuan atau profesionalisme. (Abdul Hamid Mursi 1987:156) Allah SWT meminta agar kita mengalihkan pandangan kepada apa yang ada dalam kemampuan kita, bukan ada pada apa yang berada diluar kemampuan kita. Sesungguhnya keutamaan terletak pada usaha dan kerja. oleh karena itu, janganlah kita berangan-angan sesuatu tanpa usaha dan kerja. Pendekatan Al-Quran dalam hal penentuan upah berdasarkan pertimbangan dan bakat ini merupakan salah satu sumbangan terpenting bagi kemajuan peradaban manusia. (M.A Manan 2000:188)

Dalam Islam di kenal beberapa tingkatan upah, yaitu:

\section{a. Tingkat Upah Minimum}

Pekerja dalam hubungannya dengan majikan berada dalam posisi yang sangat lemah. Selalu ada kemungkinan kepentingan para pekerja tidak dilindungi dengan baik. Mengingat posisinya yang lemah itu, Islam memberikan perhatian dalam melindungi hak para pekerja dari segala ganguan yang dilakukan oleh majikannya (Afzalurrahman 1995:366). Oleh karena itu, untuk melindungi kepentingan dari pelanggaran hak perlu ditentukan upah minimum yang dapat mencakup kebutuhan pokok hidup, termasuk makanan, pakaian, tempat tinggal dan lainnya, sehingga pekerja memperoleh kehidupan yang layak.

b. Tingkat Upah tertinggi

Bakat dan keterampilan seorang pekerja merupakan salah satu faktor upahnya tinggi atau tidak. Pekerja yang intelektual dengan pekerja kasar, atau pekerja yang handal dengan pekerja yang tidak handal, 
mengakibatkan upah berbeda tingkatnya. Selain itu perbedaan upah timbul karena perbedaan keuntungan yang tidak berupa uang, karena ketidaktahuan atau kelambanan dalam bekerja, dan masih banyak lagi faktor-faktor lainnya. Oleh karena itu, Islam memang tidak memberikan upah berada di bawah upah minimum yang telah ditetapkan, demikian halnya Islam juga tidak membolehkan kenaikan upah melebihi tingkat tertentu melebihi sumbangsih dalam produksinya. Oleh karena itu, tidak perlu terjadi kenaikan upah yang melampau batas tertinggi dalam penentuan batas maksimum upah tersebut. Setidak- tidaknya upah dapat memenuhi kebutuhan pokok pekerja dan keluarga agar tercipta keadilan dan pemerataan kesejahteraan. Pentingnya menjaga upah agar tetap berada pada batas-batas kewajaran agar masyarakat tidak cenderung menjadi pengkonsumsi semua barang konsumsi.

\section{Hikmah Upah (Ujrah)}

Hikmah disyari'ahkannya ijarah dalam bentuk pekerjaan atau upah mengupah adalah karena dibutuhkan dalam kehidupan manusia. Tujuan dibolehkannya ijarah pada dasarnya adalah untuk mendapatkan keuntungan materil. Namun, itu bukanlah tujuan akhir karena usaha yang dilakukan atau upah yang diterima merupakan sarana untuk mendekatkan diri kepada Allah SWT.

Adapun hikmah diadakannya ijarah antara lain, membina ketentraman dan kebahagiaan, memenuhi nafkah keluarga, memenuhi hajat hidup masyarakat, dan menolak kemungkaran

\section{Outsourcing}

Outsourcing di artikan sebagai contract (work) Out. Menurut definisi Maurice Greaver, outsourcing dipandang sebagai tindakan mengalih beberapa aktivitas perusahaan dan hak pengambilan keputusannya kepada pihak lain, dimana tindakan ini terikat dalam suatu kontrak kerja sama. Dapat juga dikatakan sebagai penyerahan kegiatan perusahaan baik sebagian ataupun secara menyeluruh kepada pihak lain yang tertuang dalam kontrak perjanjian. Outsourcing disamakan dengan jasa penyalur tenaga kerja. Sebenarnya outsourcing adalah pemindahan fungsi pengawasan dan pengelolaan suatu proses bisnis kepada perusahaan penyedia jasa. Ada 3 unsur penting dalam outsourcing, yaitu:

a. Pemindahan fungsi pengawasan

b. Pendelegasian tanggung jawab atau tugas suatu perusahaan

c. Menitikberatkan pada hasil atau output yang ingin di capai oleh perusahaan. 
Seiring dengan perkembangan zaman, tujuan dari outsourcing tidak hanya membagi risiko ketenagakerjaan, tetapi menjadi lebih kompleks. Outsourcing telah menjadi alat manajemen, serta bukan hanya untuk menyelesaikan masalah, tetapi untuk mendukung dan sasaran bisnis. Berdasarkan hasil survey outsourcing institute ada beberapa alasan mengapa perusahaan melakukan outsourcing. Alasan-alasan tersebut antara lain:

a. Meningkatkan fokus perusahaan

b. Memanfaatkan kemampuan kelas dunia

c. Mempercepat keuntungan yang diperoleh dari reengineering.

d. Membagi risiko.

e. Sumber daya sendiri dapat di gunakan untuk kebutuhankebutuhan lain.

f. Memungkinkan tersedianya dana kapital.

g. Menciptakan dana segar.

h. Mengurangi dan mengendalikan biaya operasi.

i. Memperoleh sumber daya yang tidak dimiliki sendiri.

j. Memecahkan masalah yang sulit dikendalikan atau dikelola.

Alasan-alasan huruf a sampai dengan e di atas merupakan target jangka panjang dan bersifat strategis, sedangkan alasan $f$ sampai dengan $\mathrm{j}$ lebih bersifat taktis atau yang mempengaruhi operasi dan bisnis perusahaan sehari-hari. (Eko dan Djoko, 2004-4)

\section{Dasar Hukum Outsourcing}

Pengaturan hukum outsourcing di Indonesia di atur dalam UndangUndang Ketenagakerjaan Nomor 13 Tahun 2003 (Pasal 64, 65, dan 66). Dalam Pasal 64 menyebutkan "perusahaan dapat menyerahkan sebagian pekerjaan kepada perusahaan lainnya melalui pemborongan pekerjaan atau penyediaan jasa pekerja yang dibuat secara tertulis"(Amin Wijaya, 2015:42)

Sedangkan Pasal 65 menyatakan:

1) penyerahan sebagian pelaksanaan pekerjaan kepada perusahaan lain di laksanakan melalui perjanjian pemborongan pekerjaan yang dibuat secara tertulis. Dalam hal ini, perusahaan dapat menyerahkan sebagian pelaksanaan pekerjaannya kepada perusahaan lain melalui: a) Pemborongan pekerjaan, atau b) Penyediaan jasa pekerja.

2) Pekerjaan yang dapat diserahkan kepada perusahaan lain sebagaimana dimaksud dalam ayat 1 harus memenuhi syarat-syarat sebagai berikut:

a. Dilakukan secara terpisah dari kegiatan utama. 
b. Dilakukan dengan perintah langsung atau tidak langsung dari pemberi pekerjaan

c. Merupakan kegiatan penunjang perusahaan secara keseluruhan, dan

d. Tidak menghambat proses produksi secara langsung

3) Perusahaan lain sebagaimana dimaksud diatas harus berbetuk badan hukum.

4) Perlindungan kerja dan syarat-syarat kerja bagi pekerja atau buruh di perusahaan lain sebagaimana dimaksud dalam ayat (2) sekurang-kurangnya sama dengan perlindungan kerja dan syaratsyarat kerja di perusahaan pemberi pekerjaan atau sesuai dengan perundang-undangan yang berlaku.

5) Perubahan dan penambahan syarat-syarat sebagaimana di maksud dalam ayat (2) di atur lebih lanjut dengan Keputusan Menteri.

6) Hubungan kerja dalam pelaksanaan pekerjaan sebagaimana di maksud pada ayat (1) di atur dalam perjanjian kerja secara tertulis antara perusahaan lain dan pekerja atau buruh yang di pekerjakannya.

7) Hubungan kerja sebagaimana dimaksud ayat (6) dapat didasarkan atas perjanjian-perjanjian kerja waktu tidak tertentu atau perjanjian kerja waktu tertentu apabila memenuhi persyaratan sebvagaimana dimaksud dalam Pasal 59.

8) Dalam hal ketentuan sebagaimana yang dimaksud pada ayat (2), ayat(3) tidak terpenuhi, maka demi hokum styatus hubungan pekerja atau buruh dengan perusahaan penerima pemborongan beralih menjadi hubungan kerja atau buruh dengan perusahaan pemberi kerja.

9) Dalam hal hubungan kerja beralih ke perusahaan pemberi pekerjaan sebagaimana yang dimaksud pada ayat (8), maka hubungan kerja pekerja atau buruh dengan pemberi pekerjaan sesuai dengan hubungan kerja sebagaimana dimaksud pada ayat (7).

Sedangkan Pasal 66 mengatur:

1) Pekerja atau buruh dari perusahaan penyedia jasa pekerja tidak boleh digunakan oleh pemberi kerja untuk melaksanakan kegiatan pokok atau kegiatan yang berhubungan langsung dengan proses produksi kecuali untuk kegiatan jasa penunjang atau kegiatan yang tidak berhubungan langsung dengan proses produksi.

2) Penyedia jasa pekerja atau buruh untuk kegiatan jasa penunjang atau kegiatan yang tidak berhubungan langsung dengan proses produksi harus memenuhi syarat sebagai berikut: 
a. Adanya hubungan kerja antara pekerja atau buruh dan perusahaan penyedia jasa pekerja atau buruh.

b. Perjanjian kerja yang berlakudalam hubungan kerja sebagaimana dimaksud pada huruf a adalah perjanjian kerja untuk waktu tertentu yang dibuat secara tertulis dan di tandatangani oleh kedua belah pihak.

c. Perlindungan upah dan kesejahteraan, syarat- syarat kerja, serta perselisihan yang timbul menjadi tanggung jawab perusahaan penyedia jasa pekerja atau buruh.

d. Perjanjian antara perusahaan pengguna jasa pekerja atau buruh dan perusahaan penyedia pekerja atau buruh dibuat secara tertulis dan wajib memuat pasal sebagaimana dimaksud dalam undang-undang ini.

3) Penyedia jasa pekerja atau buruh merupaka bentuk usaha berbadan hukum dan memiliki izin dari instansi yang bertanggung jawab di bidang ketenagakerjaan.

4) Dalam hal tertentu sebagaimana dimaksud pada ayat (1), ayat (2) huruf $a$, huruf $b$, dan huruf d serta ayat (3) tidak terpenuhi, maka demi hokum status hubungan kerja antara pekerja atau buruh dan perusahaan jasa penyedia pekerja atau buruh beralih menjadi hubungan kerja antara pekerja atau buruh dan perusahaan pemberi pekerjaan.

Untuk menentukan suatu kegiatan apakah termasuk kegiatan pokok atau kegiatan penunjang yaitu dengan melihat akibat dari keberadaan kegiatan. Apabila tanpa kegiatan tersebut perusahaan tetap dapat berjalan dengan baik, maka kegiatan itu termasuk kegiatan penunjang. Sebaliknya, apabila tanpa kegiatan yang dimaksud, proses kegiatan perusahaan menjadi terganggu dan tidak dapat berjalan, maka kegiatan itu termasuk kegiatan pokok.

\section{Outsourcing dalam Islam}

Dalam Islam sendiri memang belum di temukan teori yang menjelaskan secara komprehensif tentang outsourcing. Tetapi jika kita telaah lebih jauh tentang konsep dan unsure outsourcing tersebut, maka kita dapat qiyaskan ke dalam konsep syirkah dan ijarah. Hubungan antara perusahaan outsourcing dengan pihak pengguna jasa, diqiyaskan dalam bentuk syirkah dan hubungannya atara perusahaan outsourcing dengan para pekerjanya diqiyaskan dalam bentuk ijarah.

Dalam sistem outsourcing, perusahaan pemberi pekerjaan berkontribusi dalam hal lapangan pekerjaan dan perusahaan penyedia jasa pekerja menyediakan para pekerjanya. Disini perusahaan pemberi 
pekerjaan mempunyai lapangan kerja tetapi tidak memiliki tenaga kerjanya, maka ia bekerja sama dengan pihak penyedia jasa tenaga kerja untuk menyelesaikan pekerjaannya.

Dalam implementasinya sistem outsourcing ini, tentu para pihak yang melakukan akad kerja sama pekerjaan atau syirkah abdan haruslah disebutkan berapa nilai kontrak, jangka waktu kontrak, dan aturanaturan yang harus di sepakati oleh pihak penyedia jasa tenaga kerja. Dalam pelaksanaan syirkah abdan ini dapat juga menyertakan akad ijarah atau upah karyawan berdasarkan kesepakatan.

\section{Hasil Penelitian}

Hasil penelitian ini diperoleh dengan teknik wawancara dengan narasumber, sebagai bentuk pencarian data dan dokumentasi langsung dilapangan kemudian di analisis. Analisis ini berfokus pada Ketentuan Pengupahan Perusahaan Outsourcing dalam Pandangan Ekonomi Islam. Selain itu, peneliti juga melakukan wawancara dengan para karyawan outsourcing di lapangan. Tahapan analisis, peneliti membuat daftar pertanyaan untuk wawancara, pengumpulan data, dan dianalisis oleh peneliti sendiri. Untuk mengetahui informasi yang diberikan oleh narasumber, peneliti menggunakan tahapan sebagai berikut:

1. Menyusun draft pertanyaan wawancara berdasarkan unsur kredibilitas yang akan ditanyakan pada narasumber.

2. Melakukan wawancara dengan General Manager, HRD Manager, Finance Manager dan Karyawan PT. Sangu.

3. Melakukan dokumentasi langsung dilapangan untuk melengkapi data-data yang berhubungan dengan penelitian.

4. Memindahkan data penelitian yang berbentuk daftar dari pertanyaan yang diajukan kepada narasumber.

5. Menganalisis data hasil wawancara yang telah dilakukan.

\section{Analisis Deskriptif Hasil Penelitian}

Analisis deskriptif data penelitian ini adalah analisis data yang diperoleh dari hasil wawancara dengan para narasuber yang merupakan dari perwakilan General Manager, HRD Manager, Accounting Manager dan karywan yang ada dilapangan. Berdasarkan hasil wawancara dengan narasumber, maka penelit dapat menganalisis tentang ketentuan pengupahan dalam Ekonomi Islam yang meliputi:

1. Kontrak Tenaga Kerja di PT. Sangu

Dalam Ekonomi Islam, Problem perburuhan di atur oleh hukumhukum kontrak kerja atau Ijarah. Definisi Ijarah yaitu pemilikan jasa dari seorang ajir (orang yang di kontrak tenaganya) oleh musta"jir (orang 
yang mengontrak tenaga), serta pemilikan harta dari pihak musta"jir oleh seorang ajir. Dengan kata lain Ijarah merupakan transaksi terhadap jasa tertentu dengan di sertai kompensasi atau upah. (Nurul Huda 2008:229)

Dalam hal ini peneliti menanyakan langsung tentang "Bagaimana system kontrak atau perjanjian kerja di PT. Sangu?"diperoleh hasil sebagai berikut:

Bapak Robby Imansyah memberikan pernyataan sebagai berikut "Bentuk perjanjian yang lazim digunakan adalah Perjanjian Kerja Waktu Tertentu, didasarkan atas jangka waktu satu tahun. Setelah satu tahun kami evaluasi lagi untuk perpanjangan kontrak selanjutnya. Kalau hasil evaluasinya bagus maka pekerja itu akan di perpanjang lagi kontrak kerja nya selama satu tahun. Selanjutnya seperti itu. Dan begitu juga sebaliknya."(Wawancara 15 September 2016)

Hal yang sama juga diungkapkan oleh Bapak Aryo Hudoyo sebagai General Manager PT. Sangu, beliau menyatakan sebagai berikut: "dalam hal perjanjian kerja, kami memberikan kontrak kepada para pekerja satu tahun dan hal itu akan di perpanjang terus tiap tahunnya. Sebagai pekerja operasional seperti, cleaning service, customer service, security dan teknisi tidak ada status permanen. Hal itu di sebabkan karena PT. Sangu tidak terikat tetap dengan perusahaan pengguna jasa dari kami. Sewaktuwaktu perusahaan pengguna jasa memutuskan kontrak, hal yang sama juga kita berlakukan kepada pekerja kami."(Wawancara 15 September 2016)

Pernyataan yang sama juga di sampaikan oleh salah satu pekerja PT. Sangu sebagai cleaning service. Beliau mengatakan: "Saya di PT. Sangu sudah 6 tahun sejak gedung ini berdiri, untuk status kerjanya disini masih kontrak. Tidak ada status permanen di PT. Sangu, kecuali para petinggi PT. Sangu seperti manager dan supervisor. Setiap tahun kontrak kami di perpanjang, selama perusahaan ini juga memperpanjang kontrak kerjasama dengan PT. Sangu."(Wawancara 15 September 2016)

Dari hasil wawancara tersebut, bentuk perjanjian kerja outsourcing di PT. Sangu merupakan perjanjian kerja waktu tertentu (PKWT). PKWT merupakan perjanjian antara pekerja dengan perusahaan untuk mengadakan hubungan kerja dalam waktu tertentu atau untuk pekerjaan tertentu. Tiap pekerjaan yang halal maka hukum perjanjiannya juga halal. Di dalam ijarah tersebut harus tertulis jenis atau bentuk pekerjaan yang harus di lakukan seorang ajir. Jenis pekerjaan harus di jelaskan sehingga tidak kabur, karena transaksi ijarah yang masih kabur hukumnya adalah fasid (rusak). (Nurul Huda, 2008:230) 


\section{Ketentuan Upah di PT. Sangu}

Dalam menerapkan ketentuan pengupahan terhadap para pekerja PT. Sangu, besarnya upah maupun waktu pembeyarannya mengikuti peraturan pengupahan yang di terapkan oleh perusahaan pengguna jasa. Terkait hal ini, peneliti memberikan pertanyaan kepada narasumber kunci dari manager keuangan Ibu Ita selaku yang menentukan upah tenaga kerja outsourcing PT. Sangu. "Bagaimana sistem pengupahan bagi para tenaga kerja PT. Sangu?"

Ibu Ita memberikan pernyataan sebagai berikut. "Dalam hal memberikan upah atau gaji, PT. Sangu menggunakan system pre financing. Maksudnya yaitu seluruh biaya tenaga kerja, seperti gaji, upah lembur, jamsostek dan lain-lain dihitung dan ditagihkan terlebih dahulu ke perusahaan pengguna jasa oleh PT. Sangu. Selanjutnya, setelah dilakukan pembeyaran oleh perusahaan pengguna jasa, PT. Sangu melakukan pembayaran kepada tenaga kerja yang ditempatkan di perusahaan klien." (Wawancara 15 September 2016)

Selanjutnya peneliti melakukan wawancara dengan pertanyaan yang lain kepada narasumber yang sama mengenai "bagaimana cara PT. Sangu mengambil keuntungan? Apa dari potongan gaji pokok karyawan?"

Ibu Ita memberikan pernyataan sebagai berikut, "Dalam hal pengambilan keuntungan PT. Sangu menerapkan dua sistem fee managemen, yaitu recruitmen service fee dan paying agen fee. Misalkan PT. Sangu sanggup menyediakan 10 orang untuk posisi cleaning service, dan dari jasa penyediaan tenaga kerja tersebut oleh perusahaan klien di hargai sesuai kesepakatan perjanjian kerjasama. Jadi dalam hal pengupahan yang diterapkan oleh kami terhadapa para tenaga kerja tidak ada pemotongan dari gaji pokoknya. Adapun pemotongan hanya digunakan untuk jaminan social sebesar 2\%. Dan 4,24\% nya menjadi tanggung jawab perusahaan pengguna jasa outsourcing." (Wawancara 15 September 2016)

Selanjutnya peneliti melakukan wawancara dengan beberapa pekerja PT. Sangu yang ditempatkan di perusahaan klien PT. Sangu mengenai upah yang di terima, apakah sudah sesuai dengan perjanjian atau kontrak kerjanya.

Adapun pernyataan dari salah satu pekerja yang mewakili pekerja yang lain yaitu upah yang mereka terima sesuai dengan perjanjian kontrak yang mereka tandatangani. Dalam hal potongan dari upah yang diterima memang ada tetapi potongan itu untuk biaya jaminan sosial dan pajak.

Dalam hal ini peneliti menyimpulkan dari semua jawaban narasumber, bahwa upah yang mereka terima sesuai dengan perjanjian 
yang mana besarnya upah yang di terima pekerja di sebutkan didalam perjanjian tersebut. Tidak ada pemotongan apapun selain pemotongan untuk biaya jaminan sosial.

\section{Pembahasan Hasil Penelitian}

Hasil penelitian di atas merupakan proses penelitian lapangan yang telah di lakukan peneliti selama 1 hari dan telah di bahas pada Bab III Metodologi Penelitian, bahwa penelitian ini menggunakan metode kualitatif dengan pendekatan deskriptif mengenai Aplikasi Ketentuan Pengupahan Dalam Perspektif Ekonomi Islam di Perusahaan Outsourcing.

\section{Kontrak Kerja Dalam Perspektif Ekonomi Islam}

Kontrak kerja dalam Islam atau Ijarah merupakan kelayakan dari orang-orang yang melakukan akad, yaitu pengusaha dengan orang yang di kontrak, perjanjian atau akad dalam Islam dipandang sah jika rukun dan syaratnya terpenuhi. Rukun yang dimaksud adalah unsur yang membentuk perjanjian tersebut seperti menurut jumhur ulam terdiri dari tiga aspek yaitu subyek akad, objek akad dan sighat akad. Adapun di antara syarat-syarat akadnya sendiri yaitu ahliyatul „ada dan ahliyatul wujub. Kelayakan tersebut meliputi:

1. Kerelaan dua orang yang bertransaksi

Hukum yang berlaku dalam masalah upah, sebenarnya kembali kepada keridhaan kedua belah pihak yang telah disepakati di awal perjanjian. Sebagaimana bentuk perjanjian kerja antara PT. Sangu dengan tenaga kerja harus berdasarkan kesepakatan. Untuk membuktikan kesepakatan, maka dalam perjanjian tersebut harus ditandatangani oleh kedua belah pihak.

2. Jelas upah dan manfaat yang di dapat

Masalah akad pekerjaan penting di pahami dalam satu persepsi yang sama oleh pihak perusahaan dan tenaga kerja. Akad pekerjaan akan menjadi syarat dan pedoman dalam bekerja karena hal itu mengikat kedua belah pihak. (M.I. Yusanto 2002:192). Hal-hal yang terkait dengan kesepakatan kerja dapat di uraikan sebagai berikut:

a. Ketentuan kerja

Ijarah merupakan memanfaatkan jasa seseorang yang di kontrak untuk dimanfaatkan tenaganya. Kontrak kerjanya harus ditentukan bentuk kerjanya, waktu, upah serta tenaganya. Waktunya juga harus di tentukan, misalnya harian, bulanan atau tahunan. Selain itu, upah kerjanya juga harus di tetapkan. 
b. Waktu kerja

Menurut UU No.13/2003 Pasal 59 Ayat 4, Perjanjian Kerja Waktu Tertentu (PKWT) hanya boleh dilakukan paling lama dua tahun dan hanya boleh diperpanjang satu kali untuk jangka waktu paling lama satu tahun. Perusahaan yang bermaksud memperpanjang PKWT tersebut, harus memberitahukan maksudnya untuk memperpanjang PKWT secara tertulis kepada pekerja yang bersangkutan, paling lama tujuh hari sebelum PKWT berakhir. Jika perusahaan tidak memberitahukan perpanjangan PKWT ini dalam waktu tujuh hari, maka perjanjian kerjanya batal demi hukum dan menjadi Perjanjian Kerja Waktu Tidak Tertentu (PKWTT), seperti yang diatur UU No.13/2003 Pasal 59 Ayat 5.

Hal ini juga ditegaskan dalam Pasal 3 Ayat 2 Keputusan Menteri Tenaga Kerja dan Transmigrasi Republik Indonesia Nomor KEP.100/MEN/VI/2004 Tentang Ketentuan Pelaksanaan Perjanjian Kerja Waktu Tertentu, bahwa PKWT hanya dibuat untuk paling lama tiga tahun. PKWT yang dilakukan melebihi waktu tiga tahun, maka perjanjian kerjanya batal demi hukum dan menjadi PKWTT dengan kata lain pekerja tersebut menjadi pekerja permanen - UU No.13/2003 Pasal 59 Ayat 7.

c. Hubungan kerja

Hubungan kerja dalam outsourcingterjadi terhadap tiga objek yaitu pihak perusahaan outsourcing sebagai vendor atau pensuplai dan penyedia tenaga kerja. Dalam penyediaan jasa pekerja outsourcing, ada dua tahapan perjanjian yang harus di lakukan, yaitu:

1) Perjanjian antara perusahaan pemberi pekerjaan dengan perusahaan penyedia pekerjaan.

2) Perjanjian perusahaan penyedia pekerja dengan karyawan.

Dua perjanjian kerja tersebut, maka hubungan kerja yang terjadi adalah karyawan yang sehari- harinya bekerja di perusahaan pemberi pekerjaan. Status pekerja tersebut merupakan karyawan perusahaan penyedia pekerja. Pemenuhan hak-hak karyawan seperti perlindungan upah dan kesejahteraan, syarat-syarat kerja serta perselisihan yang timbul tetap merupakan tanggung jawab PT. Sangu sebagai perusahaan penyedian jasa pekerja.

Antara musta"jir dan mu"jir terikat perjanjian selama waktu tertentu sesuai kesepakatan. Selama waktu itu pula, kedua belah pihak menjalankan kewajiban dan menerima hak masing-masing. Dalam akad ijarah ini musta"jir tidak dapat menguasai mu"jir, 
karena status mu"jir adalah mandiri dan hanya di ambil manfaatnya saja. Dalam outsourcing terdapat dua kali bentuk ijarah, yaitu:

Pertama, ijarah dalam arti sewa-menyewa yang terjadi pada perusahaan outsourcing dengan perusahaan penggunanya dimana perusahaan penyewa ataupum mengambil manfaat dari tenaga kerja yang bias di manfaatkan oleh perusahaan pengguna untuk meningkatkan produktifitas perusahaan

Kedua, ijarah dalam arti upah mengupah yang terjadi antara karyawan dengan perusahaan outsourcing, yakni perusahaan outsourcing memanfaatkan keahlian dari karyawan untuk pekerjaannya. Maka karyawan juga berhak untuk mendapat upah dari kerja yang telah di laksanakan. Kerja yang dilakukan oleh karyawan adalah mempunyai waktu yang telah di tentukan oleh perusahaan outsourcing. (M. Syafii 2008:10)

Kontrak kerja antara pengusaha dan pekerja adalah kontrak kerja sama yang harusnya saling menguntungkan. Pengusaha di untungkan karena memperoleh jasa dari pekerja untuk melaksanakan pekerjaan tertentu yang dibutuhkan pengusaha. Sebaliknya, pekerja di untungkan karena memperoleh penghasilan dari imbalan yang di berikan pengusaha karena memebrikan jasa kepada pengusaha. Karena itulah, hubungan ketenagakerjaan didalam pandangan Islam adalah hubungan yang seharusnya saling menguntungkan tidak boleh satu pihak menzalimi dan di zalimi oleh pihak lainnya.

d. Berakhirnya Akad

PKWT berakhir pada saat berakhirnya jangka waktu yang di tentukan dalam klausul perjanjian kerja. Menurut Undang-undang ketenagakerjaan Pasal 61 ayat (1) perjanjian kerja berakhir sebagai berikut:

1) Pekerja meninggal dunia

2) Berakhirnya jangka waktu perjanjian kerja

3) Adanya putusan pengadilan atau penetapan lembaga penyelesaian perselisihan hubungan industrial yang telah mempunyai kekuatan hukum tetap.

4) Adanya keadaan atau kejadian yang di cantumkan dalam perjanjian kerja, peraturan perusahaan, atau perjanjian kerja bersama yang dapat menyebabkan berakhirnyan hubungan kerja.

Jika salah satu pihak mengakhiri hubungan kerja sebelum berakhirnya jangka waktu yang di tetapkan dalam perjanjian kerja waktu tertentu, atau berakhirnya hubungan kerja bukan karena 
hal-hal yang di atas, maka pihak yang mengakhiri hubungan kerja diwajibkan membayar ganti rugi kepada pihak lainnya sebesar upah pekerja sampai batas waktu berakhirnya jangka waktu perjanjian kerja.

Dalam penelitian ini dilakukan penganalisisan terkait penerapan sistem kerja kontrak di PT. Sangu yang di tinjau menurut konsep Ekonomi Islam. Peninjauan ini ditujukan untuk mengetahui apakah dalam penerapan sistem kerja kontrak tersebut mecapai kemaslahatan bagi pekerjanya. Untuk mencapai kemaslahatan tersebut terdapat lima unsur yang harus dicapai yaitu perlindungan terhadap agama, perlindungan terhadap jiwa, perlindungan terhadap akal, perlindungan terhadap keturunan dan perlindungan terhadap harta.

1. Perlindungan terhadap agama

Pemeliharaan terhadap Agama merupakan tujuan pertama Hukum Islam. Sebabnya adalah karena agama merupakan pedoman hidup manusia, dan di dalam Agama Islam selain komponen-komponen akidah yang merupakan sikap hidup seorang muslim, terdapat juga syariat yang merupakan sikap hidup seorang muslim baik dalam berhubungan dengan Tuhannya maupun dalam berhubungan dengan manusia.

Perlindungan terhadap agama dilakukan dengan memelihara dan melaksanakan kewajiban keagamaan, serta menjalankan ketentuan keagamaan atau petunjuk agama guna menjunjung tinggi martabat manusia sekaligus melengkapi pelaksanaan kewajiban terhadap Allah SWT. Perlindungan terhadap agama dimaksudkan agar eksistensi agama tetap terjaga dan segala tindakan manusia tidak keluar dari koridor syariah.

Dalam penerapan sistem kerja kontrak terhadap pekerja PT. Sangu, pihaknya telah melaksanakan kewajiban untuk memenuhhi hak-hak karyawan kontrak sesuai dengan perjanjian kontrak. Seperti hak gaji, hak atas uang ganti rugi, uang lembur, hak atas jaminan sosial tenaga kerja, hak untuk libur dan sebagainya. Terutama untuk hak ibadah pun telah terpenuhi.

Dalam hal ini perlindungan terhadap agama telah terpenuhi. Karena tidak ada pembatasan terhadap hak untuk beribadah dalam bekerja bagi para pekerja outsourcing dan berbagai kegiatan keagamaan pun telah dilaksanakan.

2. Perlindungan terhadap jiwa

Pemeliharaan terhadap jiwa merupakan tujuan dari syariat Islam. Memelihara kelestarian hidup dengan memenuhi kebutuhan pokok berupa makanan dan minuman untuk mempertahankan hidup sangatlah diperlukan. Apabila pemenuhan terhadap kebutuhan pokok terabaikan, 
maka akan membahayakan kelangsungan hidup dan mengancam eksistensi jiwa.

Dalam penerapan sistem kerja kontrak terhadap pekerja PT. Sangu, perlindungan terhadap jiwa belum sepenuhnya terpenuhi. Praktek kerja kontrak PT. Sangu merupakan salah satu bentuk penyalahan dalam konsep menjaga jiwa (hifzh an-nafs) dalam Ekonomi Islam. Karena upah yang diberikan untuk pekerja outsourcing masih terbilang kecil dari gaji pekerja tetap. Sebuah ketidak adilan karena meskipun kontribusi yang diberikan pekerja outsourcing cukup besar terhadap perusahaan, pekerja outsourcing mendapatkan upah tanpa bonus tambahan seperti yang didapatkan terhadap pekerja tetap.

Meskipun pemberian upah terhadap pekerja outsourcing PT. Sangu sesuai dengan Upah Minimum Provinsi (UMP), namun dengan penghasilan tersebut dalam pemenuhan kebutuhan hidup bagi karyawan yang telah berkeluarga tidak sepenuhnya kebutuhan mereka dapat terpenuhi. Selain itu dengan status kerja mereka sebagai pegawai outsourcing tidak menutup kemungkinan akan terjadi pemutusan kerja dari pihak pengguna jasa. Selain itu juga perubahan status kerja dari pegawai outsourcing menjadi pegawai tetap pun sangat diharapkan mereka. Dalam hal ini jiwa seseorang pekerja merasa teranca, karena mereka merasakan ketidakamanan dari status kerja mereka yang dalam bentuk kontrak tersebut.

3. Perlindungan terhadap akal (hifzh al-„aqI)

Pemeliharaan terhadap akal atau fikiran sangatlah diperlukan guna pengembangan ilmu pengetahuan kearah yang lebih baik. Sangat tidak dianjurkan untuk menuntut ilmu yang bertentangan dengan aturan syariah. Hal tersebut akan merusak pemikiran seseorang dan akan berakibat fatal terhadap akal dan kejiwaan seseorang. Pengetahuan yang baik akan berpengaruh terhadap akal dan pembentukan jiwa seseorang menjadi lebih baik lagi.

Dalam penerapan sistem kerja kontrak di PT. Sangu, perlindungan terhadap akal belum sepenuhnya terpenuhi. Dikarenakan praktek kerja kontrak di PT. Sangu dapat menghambat pekerja dalam bentuk pengembangan pengetahuan. Pengembangan pengetahuan pekerja kontrak terhambat karena tidak adanya kesempatan untuk meningkatkan jenjang karir meskipun dengan latar pendidikan dan jenis pekerjaan yang tidak jauh berbeda dengan pekerja tetap.

4. Perlindungan terhadap keturunan (hifzh an-nasl)

Perlindungan terhadap keturunan dapat dilakukan dengan menganjurkan segala hal-hal yang baik yang sesuai dengan aturan syariah dalam setiap perbuatan. Menghindarkan dari hal-hal yang dapat 
membahayakan kelangsungan keturunan dan melanggar aturan agama. Serta melindungi keturunan dari segala ancaman terhadap eksistensi keturunan. Dan juga menjamin kelangsungan hidup keturunan.

Dalam penerapan sistem kontrak di PT. Sangu, perlindungan terhadap keturunan belum sepenuhnya terpenuhi. Dikarenakan status para pekerja yang masih bersifat kontraksehingga menimbulkan rasa tidak aman bagi pekerja tersebut. Bagi para pekerja yang belum berkeluarga mungkin status kerja mereka tidak menjadi masalah. Namun bagi pekerja kontrak yang telah berkeluarga, ketidakpastian status kerja mereka sangatlah menjadi masalah baginya. Karena mereka memiliki anak dan istri yang merupakan tanggungan dari seorang kepala keluarga. Sudah merupakan kewajiban bagi seorang kepala keluarga untuk memenuhi semua kebutuhan hidup keluarganya demi kelangsungan hidup mereka.

Dengan status pekerja yang bersifat kontrak dan ketidakpastian masa kerja yang dianggap tidak layak lagi bagi mereka untuk bekerja, maka otomatis mereka akan mengalami yang namanya pemutusan hubungan kerja (PHK). Hal itu tentulah akan mengancam dan memberikan rasa tidak aman bagi pekerja outsourcing tersebut. Jika pemutusan hubungan kerja telah dilakukan, maka mereka tidak akan bisa memenuhi kebutuhan hidup nak dan istri mereka.

5. Perlindungan terhadap harta (hifzh al-maal)

Pemeliharaan terhadap harta mengenai tata cara kepemilikan harta dan larangan mengambil harta orang lain dengan cara yang tidak sah. Apabila aturan tersebut dilanggar, maka berakibat terancamnya eksistensi harta. Perlindungan terhadap harta juga dapat dilakukan dengan menghindarkan dari perbuatan pencurian serta penipuan harta. Sangat dianjurkan untuk menggunakan harta agar tetap berada di jalan Allah SWT.

Dari hasil penelitian di PT. Sangu, para pekerja outsourcing telah mendapatkan harta dengan cara yang baik. Mereka mendapatkan hak mereka dalam bekerja berupa pemberian upah yang sesuai dengan perjanjian kontrak. Mereka juga mendapatkan uang dari kegiatan di luar jam operasional kerja, seperti mendapatkan upah lembur dari kelebihan jam kerja. Dalam hal ini perlindungan terhadap harta kepemilikan terlah terpenuhi dengan baik, dan keutuhan harta tetap terjaga.

Setelah dilakukan penganalisisan berdasarkan konsep syariah terhadap penerapan sistem kerja kontrak di PT. Sangu, maka dapat ditarik sebuah kesimpulan bahwa konsep kerja kontrak outsourcing yang saat ini di praktekan di PT. Sangu sudah menyalahi beberapa konsep penerapan 
ketentuan kontrak kerja dalam Ekonomi Syariah. Yaitu penyalahan terhadap perlindungan jiwa, akal dan keturunan.

Penyalahan tersebut menyebabkan tidak tercapainya kemashlahatan secara utuh, dan akan mengakibatkan konsep efisiensi yang diharapkan akan berbalik menjadi penghalang terwujudnya efisiensi untuk jangka panjang. Ancaman kerugian akan menghampiri karena kurangnya loyalitas dan etos kerja pekerja outsourcing akibat ketidakpastian status kerja, Penghambatan jenjang karir dan juga perbedaan gaji. Konsep tidak terpenenuhinya sebuah keadilan dalam praktek kerja outsourcing, merupakan hal yang harus diperhatikan. Konsep upah pekerja kontrak harusnya memperhatikan kontribusi yang diberikan oleh pekerja kontrak tersebut. Bahwa tingkat upah yang diberikan kepada pekerja harus sesuai dengan usahanya, baik jenis pekerjaan maupun keahlian atau profesi pekerja itu sendiri. Jadi hasil usaha seseorang merupakan nilai dari pekerjaan manusia tersebut.

Kemashlahatan hendaknya terpenuhi secara sempurna karena Allah menginginkan aktualisasi kemashlahatan manusia dalam semua aturan hukum- nya. Allah SWT mengakui atau menyetujui semua yang bermanfaat dan menolak semua yang mendatangkan mafsadah. Karena itulah sebuah kemashlahatan harus di wujudkan secara utuh guna mencapai kebaikan di dunia dan di akhirat.

\section{Tinjauan Ekonomi Islam Terhadap Ketentuan Pengupahan OutsourcingPT. Sangu}

Dalam Ekonomi Islam disyaratkan agar upah dalam transaksi ijarah disebutkan secara jelas, sebagaimana sabda Rasulullah SAW yang artinya "Siapa yang memperkerjakan seseorang hendaklah ia memberitahukan kepadanya berapa bayarannya"(Ibnu Abi Syaibah Juz. 5 h. 129)

Hadist ini menjelasakan bahwa seorang buruh jangan sampai tidak mengetahui upahnya, karena hal itu dapat membuka peluang terjadinya proses penipuan. Islam mengharamkan segala jenis kezaliman dan mengajak dihilangkannya berbagai bencara dan keburukan yang timbul darinya.

Di antara bentuk-bentuk kezaliman yang paling jelas adalah memeras kaum buruh dan menahan upah mereka. Sesungguhnya hal itu sangat diharamkan dan sangat jelas pelarangannya karena dapat di kategorikan sebagai memakan harta yang batil.( Yusuf Qardhawi 2001:403).

Dalam menerapkan sistem pengupahan terhadap para tenaga kerja outsourcing, PT. Sangu menggunakan sistem pre-financing perusahaan klien. Seluruh biaya tenaga kerja, seperti gaji, lembur, jamsostek dan lain- 
lain dihitung dan ditagihkan terlebih dahulu ke perusahaan klien oleh PT. Sangu. Setelah dilakukan pembayaran oleh perusahaan klien, PT. Sangu baru melakukan pembayaran kepada tenaga kerja yang ditempatkan di perusahaan klien. Berikut adalah skema mekanisme pembayaran upah di PT. Sangu. Skema dibawah ini merupakan versi dan format dari penulis berdasarkan keterangan hasil wawancara.

\section{Kesimpulan}

Dari pembahasan-pembahasan sebelumnya, peneliti dapat menarik beberapa kesimpulan sebagai berikut:

Dalam Ekonomi Islam, upah merupakan bagian dari Ijarah. Di dalam pelaksanaannya ada syarat dan ketentuan yang mengikat kedua belah pihak, baik pemberi upah dan yang menerimanya. Dalam hal besar kecilnya upah, Islam mengakui terjadinya perbedaan dikarenakan beberapa sebab seperti perbedaan jenis pekerjaan, perbedaan kemampuan, keahlian dan pendidikan.

Upah yang diberikan kepada tenaga kerja outsourcingdi PT. Sangu mengikuti peraturan yang ada di perusahaan pengguna jasa outsourcing (Klien). aturan yang diikuti oleh PT. Sangu dalam hal pengupahan adalah waktu pembayaran dan besarnya upah tenaga kerja outsourcing. Upah pokok karyawan tidak ada pemotongan oleh PT. Sangu. Adapun pemotongan dari upah pokok karyawan hal itu di gunakan untuk jaminan sosial berupa BPJS sebesar 2\% dan 4\% nya menjadi beban perusahaan pengguna jasa. PT. Sangu tidak mengambil keuntungan dari upah pokok karyawan, namun keuntungannya diperoleh dari fee manajemen. Fee manajemen merupakan biaya atau bayaran yang diterima PT. Sangu dari klien atas jasa penyediaan tenaga kerja. Fee manajemen itu tidak ada hubungannya dengan tenaga kerja, akan tetapi hubungannya antara PT. Sangu dengan Perusahaan pengguna jasa. Selain upah, hak-hak tenaga kerja outsourcing uyang diberikan oleh PT. Sangu adalah hak jaminan sosisal, hak asuransi dan mendapat THR.

Secara umum ketentuan pengupahan perusahaan outsourcing yang diberlakukan PT. Sangu terhadap tenaga kerja outsourcing, bahwa konsep kerja kontrak outsourcingyang saat ini di praktekan di PT. Sangu sudah menyalahi beberapa konsep penerapan ketentuan kontrak kerja dalam Ekonomi Syariah. Yaitu penyalahan terhadap perlindungan jiwa, akal dan keturunan. Penyalahan tersebut menyebabkan tidak tercapainya kemashlahatan secara utuh, dan akan mengakibatkan konsep efisiensi yang diharapkan akan berbalik menjadi penghalang terwujudnya efisiensi untuk jangka panjang. Ancaman kerugian akan menghampiri karena kurangnya loyalitas dan etos kerja pekerja outsourcing akibat 
ketidakpastian status kerja, Penghambatan jenjang karir dan juga perbedaan gaji.

\section{Daftar Pustaka}

Afzalurrahman, Doktrin Ekonomi Islam Jilid 2, Jakarta: Dana Bhakti Wakaf,1995.

Agus, Pancawibowo, Penerapan Sistem Outsourcing dan Hak- Hak Sosial Ekonomi Tenaga Kerja di Kota Surakarta, Surakarta: USM, 2010.

Al-Husaini, Imam Taqiyuddin Abu Baker, Kifayatul Akhyar, (terj) oleh K.H Syarifuddin Anwar dan K.H Misbah Mustafa, Surabaya: CV. Bina Iman, 1994

Asikin, H. Zainal, dkk, Dasar-dasar Hukum Perburuhan, Jakarta:PT. Raja Grafindo Persada,2004.

Bilal, khan, Ayessha Farooq, Human Resource Management, India: AMU, 2010.

Depdikbud, Kamus Besar Bahasa Indonesia, Jakarta: Balai Pustaka, 1988.

Dwi, Sulistiani, Jurnal Ekonomi, Penerapan Budaya Perusahaandan Kinerja Karyawan Outsourcing Dalam Perspektif Hukum Islam, Malang: 2014

Fithriyyati, Chaliliyya, Tinjauanhukum Islam dan hukum Positif di Indonesia terhadap perjanjian kerja di PT. Pesona Cipta, Yogyakarta: 2013

Hasan Syadily, Ensiklopedia Indonesia, Jakarta: Ichtiar Baru, 1984.

Hasan, M. Ali, Berbagai Transaksi Dalam Islam (Fiqh Muamalah), Jakarta: PT. Raja Grafindo Persada, 2004. Lathif, AH. Azharudin, Fikh Muamalah, Jakarta: UIN Jakarta Press, 2005.

Herman, Setyanto, Perjanjian Kerja Dalam Undaang-Undang Nomor 13 Tahun 2003 Tentang Ketenagakerjaan menurut Hukum Islam, Surakarta: 2010

Muba, Wang, "Tenaga Kerja Outsourcing", Jakarta, 2009

Mursi, Abdul Hamid, SDM Produktif: Pendekatan dan Sains, Jakarta: Gema Insani Press, 1987.

N, Gindo, "Praktek Outsourcing Semakin Menggila", Jakarta, 2009

Qarashi, Baqir Sharif, Hak dan Peran Pekerja Dalam Islam, Jakarta: AlHuda, 2007.

Qardhawi, Yusuf, Peran Nilai dan Moral dalam perekonomian islam, (terj). K.H Didin Hafiduddin, Jakarta: Robbani Press, 2001. 
Rudi, Sugiarto, Sistem Pengupahan Pada PT. Permata Indonesia Dalam Hukum Ekonomi Islam, UIN, 2010. Sarwat, Ahmad, Sistem Memberi Upah Dalam Islam, Jakarta, 2010

Samanjuntak, Payaman P., Pengantar Ekonomi Sumber Daya Manusia, Jakarta: LPFE UI, 1998.

Sugiyono, Metode Penelitian Pendidikan, Bandung: Alfabeta, 2015.

Suwondo, Candra, Outsourcing Implementasi di indonesia, Jakarta: PT. Elex Media Komputindo, 2003.

Syaibah, Ibnu Abi, Kitab Al-Mushannif Ibnu Abi Syaibah, Juz. 5., h. 129

Tunggal, Amin Widjaja, Outsourcing Konsep dan Kasus, Jakarta: Harvarindo, 2008.

\section{WEBSITE}

Undang-undang No. 13 Tahun 2003, Pasal 64, 65,dan 66

www.assunah.or.id www.kpsmedan.org www.pkbl.bumn.go.id 